\title{
A Moral Language for Our Time? Human Rights and Christianity in Historical Perspective
}

\author{
Rachel Johnston-White \\ University of Groningen, Oude Kijk in 't Jatstraat 26, 9712 EK Groningen, the Netherlands \\ r.m.johnston-white@rug.nl
}

Marco Duranti, The Conservative Human Rights Revolution: European Identity, Transnational Politics, and the Origins of the European Convention (Oxford: Oxford University Press, 2017), 522 pp. (hb), E62.00, ISBN 978-0199-81138-0.

Steven L.B. Jensen, The Making of International Human Rights: The 1960s, Decolonization, and the Reconstruction of Global Values (Cambridge: Cambridge University Press, 2016), 326 pp. (hb), £66.00, ISBN 978-1107-11216-2.

Johannes Morsink, The Universal Declaration of Human Rights and the Challenge of Religion (Columbia: University of Missouri Press, 2017), 386 pp. (hb), £86.00, ISBN 978-0826-22084-4.

Samuel Moyn, Not Enough: Human Rights in an Unequal World (Cambridge, MA: Harvard University Press, 2019), 296 pp. (pb), £11.00, ISBN 978-0674-24139-8.

Sarah Shortall and Daniel Steinmetz-Jenkins, eds., Christianity and Human Rights Reconsidered (Cambridge: Cambridge University Press, 2020), 300 pp. (hb), £22.00, ISBN 978-11084-2470-7.

On 3 October 2020 Pope Francis issued his third encyclical, Fratelli Tutti. Signed in the symbolic location of Assisi, home of St Francis, the encyclical represented the pope's response to the fears and anxieties wrought by the COVID-19 pandemic, as well as the burning injustices of racism, global inequality and climate change. The encyclical explicitly invoked human rights, criticising the ways in which, 'in practice, human rights are not equal for all.' As nations and societies succumb to 'disenchantment and disappointment', 'the temptation to build a culture of walls' to keep out the 'other' grows ever greater. ${ }^{2}$ The antidote, Francis insisted, is a 'culture of encounter' in which it is again possible to 'rediscover the needs of the brothers and sisters who orbit around us'. ${ }^{3}$ Priority, too, must be given to 'the dignity of the poor' and 'respect for the natural environment,' rather than the privileges of the affluent to continue to amass wealth at all costs. ${ }^{4}$ Only then - by aligning human rights with the global common good - can rights become truly universal.

The encyclical itself contains clues that reveal the opponents of Francis's vision of human rights and their connection to, and claims upon, Christianity. Right-wing populists, ranging from Viktor Orbán in Hungary to Donald Trump in the United States, have seen no contradiction in mobilising Christianity to support political agendas which patently limit the rights of 'others' deemed 'culturally

\footnotetext{
1 Pope Francis, 'Encyclical Letter Fratelli Tutti of the Holy Father Francis on Fraternity and Social Friendship', vatican.va, 3 Oct. 2020, para. 22. http://www.vatican.va/content/francesco/en/encyclicals/documents/papa-francesco_20201003_enciclica-fratelli-tutti.html\#_ftnref85

2 Ibid., paras. 27, 30 .

3 Ibid., paras. $30-1$.

4 Ibid., para. 122.

(c) The Author(s), 2021. Published by Cambridge University Press. This is an Open Access article, distributed under the terms of the Creative Commons Attribution licence (http://creativecommons.org/licenses/by/4.0/), which permits unrestricted re-use, distribution, and reproduction in any medium, provided the original work is properly cited.
} 
[in] compatible' with their particular vision of the nation. ${ }^{5}$ Yet such debates over the political meaning of Christianity and the uses of human rights are hardly new. Even the teachings of the Vatican itself have not always been as clear as they appear in Fratelli Tutti, in particular on whether human rights align with or, rather, threaten the mission of the Catholic Church. Indeed, the reconciliation of the Catholic Church with human rights dates only to the 1960s, as Carlo Invernizzi Accetti and others have shown. ${ }^{6}$ The enduring question is whether the 'rights' which the Church now embraces are the same rights enshrined in international law and in liberal, secular interpretations of human rights. ${ }^{7}$

While advocating an expansive interpretation of rights in some respects, such as environmental rights for the planet, Fratelli Tutti echoes older Catholic criticisms of 'individualistic' rights, which consider only the individual at the expense of the 'greater good' or of social groups such as the family, religious institutions, trade unions and wider civil society. ${ }^{8}$ 'Limitless' rights, which grant each person permission to run roughshod over the freedoms and needs of others, appear just as much of a threat in this latest encyclical as they do in mid-twentieth-century papal cautionary warnings against an uncritical acceptance of (secular) human rights. ${ }^{9}$ As the example of Fratelli Tutti shows, human rights continue to capture the moral imagination of religious institutions and political actors alike. However, setting aside the triumphalist 'end of history' claims that accompanied the end of the Cold War, ${ }^{10}$ much of the appeal of human rights lies in their inherent malleability. They can be interpreted and re-interpreted to suit a staggering variety of ideologies, religious persuasions and political regimes. Yet it is precisely this malleability that makes it difficult to put human rights to the purpose of enacting a truly just society, as Samuel Moyn argues in his latest book. ${ }^{11}$ As the works discussed below reveal, untangling the relationship between Christianity and human rights depends upon understanding what is meant by each and in what context. Further complicating this task is that interpretations of both Christianity and human rights are constantly evolving, responding to ongoing political, legal and cultural shifts. More than ever, it is urgent to understand this relationship, to historicise it and to clarify the uses that have been and are being made of these two sets of ideals.

The most recent research on human rights and its connection to Christianity builds upon existing work by historians, religious studies scholars, legal theorists and political scientists by taking up several central threads of debate. The first of these is the question of the role Christianity plays in the origins of ideas about rights, their institutionalisation in law and as norms, and in the interpretation of their meaning. Which strands of Christianity, or indeed Christian figures and movements, had influence on the emergence of ideas about rights? Related to this is the question of the intellectual genealogy of human rights. Are rights primarily secular in origin, coming out of the Enlightenment anti-clerical tradition, or do they also have important religious origins? If the latter, do those origins include

5 Tobias Müller, 'Constructing Cultural Borders: Depictions of Muslim Refugees in British and German Media', Zeitschrift für Vergleichende Politikwissenschaft 12 (2018), 263-77, 270.

6 See Carlo Invernizzi Accetti, 'Catholic Social Doctrine and Human Rights: From Rejection to Endorsement?', Humanity 9, 2 (2018), 271-95, reprinted in Sarah Shortall and Daniel Steinmetz-Jenkins, eds., Christianity and Human Rights Reconsidered (Cambridge: Cambridge University Press, 2020). See also Samuel Moyn, Christian Human Rights (Philadelphia, PA: University of Pennsylvania Press, 2015); James Chappel, Catholic Modern: The Challenge of Totalitarianism and the Remaking of the Church (Cambridge, MA: Harvard University Press, 2018), 61; and Giuliana Chamedes, A Twentieth-Century Crusade: The Vatican's Battle to Remake Christian Europe (Cambridge, MA: Harvard University Press, 2019).

7 For further reflections on this question, see the introduction to Sarah Shortall and Daniel Steinmetz-Jenkins, eds., Christianity and Human Rights Reconsidered (Cambridge: Cambridge University Press, 2020), 7.

8 Pope Francis, 'Encyclical Letter Fratelli Tutti of the Holy Father Francis on Fraternity and Social Friendship', vatican.va, 3 Oct. 2020, para. 111. http://www.vatican.va/content/francesco/en/encyclicals/documents/papa-francesco_20201003_enciclica-fratelli-tutti.html\#_ftnref85.

9 Ibid. See also Invernizzi Accetti's discussion of Pope Pius XII's distinction between the human 'person' and the 'individual', as well as the rights to which each of these figures should be entitled, in Shortall and Steinmetz-Jenkins, eds., Christianity and Human Rights Reconsidered (Cambridge: Cambridge University Press, 2020), 89-90.

10 See Francis Fukuyama's eponymous The End of History and the Last Man (Harmondsworth: Penguin, 1992).

11 Samuel Moyn, Not Enough: Human Rights in an Unequal World (Cambridge, MA: Belknap/Harvard University Press, 2018). 
other religions besides Christianity? Should scholars and practitioners of human rights acknowledge multiple strands of influence, or is the evidence instead pointing towards a consensus about both the timing of the emergence of human rights on the global stage and the factors that influenced this? These questions preoccupied an earlier generation of religious studies scholars, theologians and legal theorists, including John Witte, M. Christian Green, Frank Alexander, David Novak and David Little, whose investigations of Christian and Jewish influences on rights have done much to promote the idea of the inherent compatibility between 'Judeo-Christianity' and human rights. ${ }^{12} \mathrm{~A}$ new generation of historians, including Sarah Shortall, Marco Duranti, Udi Greenberg, Daniel Steinmetz-Jenkins, James Chappel, Giuliana Chamedes and Piotr Kosicki, among others, have also tackled these issues in recent archivally-based works. ${ }^{13}$

The second subject of debate relates to the political nature of human rights and the social and cultural effects rights have had, both on particular communities and the world more broadly. This, in turn, begs the question that both Moyn and Johannes Morsink - and, to a lesser extent, Stephen Jensen - take up in their monographs regarding the political and moral use to be made of human rights in the present and future. Should human rights be embraced and brought into dialogue with world religious traditions, as Morsink advocates, or should they instead be dramatically reshaped for the sake of global justice, as Moyn urges? Or, perhaps, a different 'utopian' project awaits that might replace human rights altogether? ${ }^{14}$

Although starting from radically different assumptions about the origins, purpose and prestige of human rights, the works under consideration in this essay broadly engage with one or other of these two debates. Duranti, Shortall and Steinmetz-Jenkins are fundamentally concerned with the complex relationship between Christianity and human rights in the past, whereas Moyn and Morsink write primarily with an eye to the future. Jensen's work strives for a balance between these preoccupations, focusing on debunking the notion of human rights as a 'Western' imposition by re-centring the developing world in order to benefit contemporary human rights politics. I will begin with historical perspectives on human rights and the connection to Christianity.

Marco Duranti's magisterial monograph, The Conservative Human Rights Revolution: European Identity, Transnational Politics, and the Origins of the European Convention, investigates the origins

12 See John Witte and M. Christian Green, eds., Religion and Human Rights: An Introduction (Oxford: Oxford University Press, 2012); John Witte and Frank S. Alexander, Christianity and Human Rights: An Introduction (Cambridge: Cambridge University Press, 2010); David Novak, Covenantal Rights: A Study in Jewish Political Theory (Princeton, NJ: Princeton University Press, 2000); David Little, Essays on Religion and Human Rights: Ground to Stand On (New York: Cambridge University Press, 2015); Sumner B. Twiss, Marian Gh. Simion and Rodney L. Petersen, eds., Religion and Public Policy: Human Rights, Conflict, and Ethics (New York: Cambridge University Press, 2015); Frances S. Adeney and Arvind Sharma, Christianity and Human Rights: Influences and Issues (Albany: State University of New York Press, 2007); Elisabeth A. Diamantopoulou and Louis-Léon Christians, eds., Orthodox Christianity and Human Rights in Europe: A Dialogue between Theological Paradigms and Socio-Legal Pragmatics, Gods, Humans and Religions, vol. 24 (Brussels: P.I.E. Peter Lang, 2018); and Linda Hogan, Keeping Faith with Human Rights (Washington, DC: Georgetown University Press, 2015).

13 See the excellent 'Special Forum on Christianity and Human Rights', Journal of the History of Ideas, 79, 3 (2018), 407-95, edited by Udi Greenberg and Daniel Steinmetz-Jenkins; Piotr Kosicki, 'Masters in Their Own Home or Defenders of the Human Person? Wojciech Korfanty, Anti-Semitism, and Polish Christian Democracy's Illiberal Rights-Talk', Modern Intellectual History, 14, 1 (2017), 99-130; Chappel, Catholic Modern; Chamedes, A Twentieth-Century Crusade; Marco Duranti, The Conservative Human Rights Revolution: European Identity, Transnational Politics, and the Origins of the European Convention (Oxford: Oxford University Press, 2017); Sarah Shortall, Soldiers of God in a Secular World: The Politics of Theology in Twentieth-Century Europe (Cambridge, MA: Harvard University Press, 2021); see also Rachel M. Johnston-White, 'A New Primacy of Conscience? Conscientious Objection, French Catholicism and the State during the Algerian War', Journal of Contemporary History, 54, 1 (2019), 112-38.

14 Sam Moyn argues that human rights should be understood as a utopian project in his book The Last Utopia (Cambridge, MA: Belknap/Harvard University Press, 2010). For Moyn, human rights filled the void left behind by the failure of previous utopian projects, such as socialism, in the 1970s. 
of the European Convention on Human Rights (ECHR), arguing that we should understand the ECHR as an essentially conservative and reactionary project at the time of its creation. For the political right in Britain and France, Duranti demonstrates, the ECHR acted as a tool to claw back power from parliamentary democracy after 1945. Dismayed by the electoral success of their domestic left-wing rivals, Churchill and the British Tories aligned with French Catholic social conservatives to pursue a shared agenda: the construction of a supranational legal system to 'constrain the exercise of sovereign power' by the socialist left. ${ }^{15}$ These conservative champions of human rights succeeded in making the ECHR an entirely different beast than the Universal Declaration of Human Rights (UDHR), then only a few years old. Invoking the necessity of a new moral language, Western European conservatives claimed human rights as a tool to protect individual freedoms and the rule of law, as well as Europe's Christian heritage, from secular 'totalitarianism' (read: socialism). ${ }^{16}$ The most important innovation of the resulting European Court of Human Rights was its mandate to transcend the sovereignty of European nation-states; indeed, it was the first judicial institution with such powers. Duranti convincingly explains the suspicion with which the British and French left viewed the proposed ECHR, while offering a comprehensive intellectual history of conservative aims in championing a European human rights court.

The latter ranged widely and tended to differ on the two sides of the channel. Champions of human rights were ideologically eclectic 'adherents of mid-twentieth-century neoliberalism and counterrevolutionary social conservatism' who sought a way to re-legitimise the right after the calamitous war years. ${ }^{17}$ Their vision of human rights prioritised civil liberties, rather than the social rights enshrined in the UDHR. Yet their specific political and ideological aims diverged. Winston Churchill led one faction of convinced European imperialists, for whom human rights functioned as justification for the continuation of European domination in the wider world. Duranti depicts him as an unflinching champion of European integration by showing how his vision of a more unified Europe supported, rather than contradicted, his devotion to the British empire and to European imperialism more broadly. Churchill's vision of rights, and the version he helped to install in the new ECHR, only embraced Europeans, thus preventing anti-colonial activists from seizing human rights for their own agenda. The other British faction in support of the ECHR were free-market fundamentalists, of which politician David Maxwell Fyfe was leader. Where Churchill looked to empire, Maxwell Fyfe's preoccupations tended towards the domestic, namely curtailing the ability of the British Labour government to enact its policies. He looked to the ECHR as a supranational mechanism to limit state power at home, while also stymying the expansion of socialism in Europe.

It was on the French side of the channel, however, that Christianity acted as a crucial political force. French advocates of the ECHR tended to be devout Catholics whose convictions ranged from socially conservative to reactionary and even anti-Semitic. They shared Maxwell Fyfe's desire to constrain state power, but where Fyfe and his ilk fought the state in the name of free-market fanaticism, French right-wing Catholics pursued an overtly moral agenda of imposing 'Christian norms' as a bulwark against communism. ${ }^{18}$ Duranti reveals the ideological complexity of this agenda. In practical terms, conservative Catholics wanted the ECHR to safeguard the rights of Catholic families to religious education with the help of state funding, a long-time preoccupation of the Catholic Church under Popes Pius XI and XII. ${ }^{19}$ Some used the new court to seek pardons for French figures who had previously collaborated with the Nazi occupiers. Yet their political aspirations extended far beyond these goals; they intended to reinstall 'old moral codes' based upon 'Christian humanist values' to the centre of a new world order. ${ }^{20}$

\footnotetext{
15 Duranti, The Conservative Human Rights Revolution, 8.

16 Ibid., 5 .

17 Ibid., 369.

18 Ibid., 8 .

19 Giuliana Chamedes, A Twentieth-Century Crusade: The Vatican's Battle to Remake Christian Europe (Cambridge, MA: Harvard University Press, 2019), 171. These two popes were also concerned with the 'right to association', which for them meant safeguarding the ability of Catholic Action to operate within civil society.

20 Ibid., 50, 99
} 
Here, Duranti is in dialogue with the latest work on the history of Christianity and its intersection with the broader history of twentieth-century Europe. As Chappel, Moyn, Chamedes, Kosicki and Shortall, among others, have demonstrated, 'Catholicism' represented a viable model of political thought in the early to mid-twentieth century. ${ }^{21}$ Pre-1945 Catholic politics ostensibly argued for an alternative to both liberalism, with its objectionable emphasis on secular individualism, and 'totalitarianism,' especially communism, which subsumed individuals, natural law and Christian morality alike into the jaws of an all-consuming state. ${ }^{22}$ In practice, a majority of European Catholics, from France to the Iberian Peninsula and from the German-speaking world to Slovakia and Croatia, looked to fascist, clerical-authoritarian and reactionary regimes when faced with the rising threat of communism. Everywhere but the Iberian Peninsula, however, the war destroyed the political and moral credibility of the Catholic-authoritarian alliance, as Chappel demonstrates, forcing Catholics to seek a new political way forward. The Catholic conservatives in Duranti's narrative found that path in human rights and the creation of the ECHR. ${ }^{23}$

Duranti's work neatly complements Moyn's narrative in his 2015 book Christian Human Rights. Both historians uncover the influence of Christianity - especially Catholicism - in the creation of human rights norms in the years immediately preceding and following the Second World War. The conservative Christian origins of the notion of 'dignity' for Moyn and the conservative interpretation of rights enshrined in the ECHR for Duranti act as a cautionary tale for human rights triumphalists. Duranti, however, is far more precise in revealing the specific ills which accompanied conservative manipulation of human rights norms. Pardons for wartime collaborators, the creation of a moral veneer for European imperialism and a powerful desire to bypass parliamentary democracy provide ample justification for the argument that a conservative, often Christian, construction of rights should unsettle us and give us pause. Moyn, for his part, demonstrates these consequences less persuasively, while still offering a valuable contribution to the ongoing debates about how Christianity shaped nascent human rights norms in the transwar period. ${ }^{24}$ Yet for all their concerns about rising state power and the decline of Christian morality, Christian conservatives presided over expansive Christian democratic welfare states across much of west-central Europe in the post-war decades. Nor did their vision of human rights emerge as hegemonic in the longer term. While Moyn and Duranti have uncovered the pivotal role conservative Christians played in creating the institutions and language of contemporary human rights, it is essential to disentangle these 'original' uses of rights from the many subsequent interpretations of rights - not least by Christians with very different political and ideological inclinations.

The carefully curated selection of essays in Sarah Shortall and Daniel Steinmetz-Jenkins's edited volume Christianity and Human Rights Reconsidered are part of an ongoing interdisciplinary response to the ideas put forward in Moyn's Christian Human Rights. As is evident throughout the volume, this book has played a defining role in the field of human rights history by sparking lively debates about

\footnotetext{
21 Samuel Moyn, Christian Human Rights (Philadelphia: University of Pennsylvania Press, 2015), 35.

22 On the Catholic interpretation of 'totalitarianism', see James Chappel, 'The Catholic Origins of Totalitarianism Theory in Interwar Europe', Modern Intellectual History, 8, 3 (2011), 561-90, and Chappel, Catholic Modern: The Challenge of Totalitarianism and the Remaking of the Church (Cambridge, MA: Harvard University Press, 2018). See also Chamedes, A Twentieth-Century Crusade, 170.

23 On how Catholic conservatives came to embrace post-war democracy, including through Christian democratic parties, see Martin Conway's extensive work on the subject, especially 'Chapter 3: Debating Democracy', in Western Europe's Democratic Age, 1945-1968 (Princeton, NJ: Princeton University Press, 2020), 162-98; 'Introduction', in Tom Buchanan and Martin Conway, eds., Political Catholicism in Europe 1918-1965 (Oxford: Oxford University Press, 1996), 28-33; and 'The Age of Christian Democracy' in Thomas Albert Kselman and Joseph A. Buttigieg, eds., European Christian Democracy: Historical Legacies and Comparative Perspectives (Notre Dame, IN: University of Notre Dame Press, 2003), 43-67.

24 On the 'transwar' terminology, see Philip Nord, France's New Deal: From the Thirties to the Postwar Era (Princeton, NJ: Princeton University Press, 2010).
} 
the chronology of the emergence of human rights as well as the ideological roles they fulfilled. ${ }^{25}$ The first of four parts of the volume explicitly addresses the question of chronology by exploring 'the relationship between Christian and liberal rights theory since the French Revolution', building upon and often constructively critiquing Moyn's research on the subject. The next three parts are divided by geographical and, to a certain extent, denominational focus. Part II explores European Catholicism and human rights since the 1930s, while Part III places American Protestantism and its interactions with human rights centre stage. The articles in Part IV expand the geographical and temporal frameworks which have defined most of the existing literature, exploring case studies from China, Latin America, West Africa and Sudan.

As Shortall and Steinmetz-Jenkins explain in the introduction, their edited volume 'break[s] new ground' in revealing 'the extent to which Christian accounts of human rights and dignity frequently do not fit the prevailing rights model that has found expression in democratic constitutions and international law. ${ }^{26}$ In other words, despite an apparent global consensus on the language of rights, with phrases such as 'human rights' or 'human dignity' widely used across the religious-secular divide, what Christians - especially Catholics - actually envisioned when they deployed this language often diverged starkly from what secular advocates of human rights intended in their own discussions.

This contention underscores a key problem with both an older literature that sought religious origins for human rights and a more recent, if sometimes counterproductive, focus on identifying precise evidence of 'rights talk' in order to ascertain how, when and where human rights emerged in their current form. ${ }^{27}$ For Christians concerned with rights, secular rationales for the existence and purpose of rights often did not suffice. For instance, Catholic philosopher Jacques Maritain, an influential spokesperson and theorist of rights who insisted that natural law could reconcile religious and secular proponents of rights, nevertheless believed that rights ultimately came from God, via natural law. ${ }^{28}$ His pragmatic assertion that the delegates responsible for drafting the UDHR 'agree[d] about the rights but on condition that no one asks us why' reflected his determination to promote consensus on rights as a universal tool. ${ }^{29}$ Yet, as this volume comprehensively demonstrates, the fundamental disagreement about the origins of rights never disappeared, despite the best efforts of Christian champions of rights like Maritain. This tension regarding the origins of rights also underscores the reasons for which 'rights talk' is often absent within the chapters, with rights instead being explored through 'cognate concepts' drawn from theology, such as 'personhood', 'humanism' and 'dignity'. ${ }^{30}$ This is evident in the prominence given to theology within the volume. For Christians who sought to make use of human rights, theological frameworks such as natural law and the common good offered alternative 'objective foundations' for rights in place of secular liberal conceptions. ${ }^{31}$

25 His 2010 book The Last Utopia posited that human rights as they exist today date only to the 1970s, filling the void left behind by the failed utopian projects of the earlier part of the century. Moyn's Christian Human Rights, published in 2015 , looked instead to the 1930s and 1940s, seeing in these decades a crucial role for Catholic and Protestant conservatives on both sides of the Atlantic who first invented the concept of 'human dignity' before harnessing 'human rights' for their own ends.

26 Sarah Shortall and Daniel Steinmetz-Jenkins, Christianity and Human Rights Reconsidered (Cambridge: Cambridge University Press, 2020), 6.

27 On rights talk see, among others, Benjamin Nathans, 'Soviet Rights-Talk in the Post-Stalin Era', in Stefan-Ludwig Hoffmann, ed., Human Rights in the Twentieth Century: Human Rights in History (Cambridge: Cambridge University Press, 2011) and Dan Edelstein, 'Enlightenment Rights Talk', Journal of Modern History, 86, 3 (2014), 530-65.

28 See Jacques Maritain, The Rights of Man and Natural Law (London: Bles, 1944) and Jacques Maritain, Man and the State. 4th impression, 1955 ed. Phoenix Books, 005 (Chicago: Phoenix Books, 1951).

29 Jacques Maritain, 'Philosophical Examination of Human Rights', in United Nations Educational, Scientific and Cultural Organization, Human Rights. Comments and Interpretations: A Symposium (London: A. Wingate, 1949), 9.

30 Shortall and Steinmetz-Jenkins, Christianity and Human Rights Reconsidered, 10.

31 Ibid., 7, 22, 58, 70, 187. For more on the concept of the common good, see Jacques Maritain, The Person and the Common Good, trans. John J. Fitzgerald (Notre Dame, IN: University of Notre Dame Press, 1985); John Finnis, Human Rights and the Common Good: Collected Essays (Oxford: Oxford University Press, 2011); William A. Barbieri, 'Beyond the Nations: The Expansion of the Common Good in Catholic Social Thought', The Review of Politics, 64, 4 (Autumn 2001), 723-54; 
Theology likewise explains another central theme of the volume, which is what John Milbank calls the 'orthogonality' of 'Christian thought in relation to secular' political categories. ${ }^{32}$ The problem with categorising Christian concepts or movements as part of the political 'right' or 'left' is that they emerged not out of secular political logic but instead from 'ethical or theological' debates which cut across left-right divides. ${ }^{33}$ The non-alignment of Christian thought and secular politics explains the startlingly diverse uses of such concepts as Christian 'personalism', which could be mobilised to support anything from the collaborationist Vichy government to the Stalinist government of Poland. ${ }^{34}$ Perhaps the only common preoccupation of a sizeable portion of Christians in the twentieth century was a critique of the liberal order. Yet here, too, denominational, geographical and political divides remained. For example, Catholics - for a variety of historical reasons which Greenberg explores in his chapter - tended towards greater mistrust of the state than did Protestants, who enjoyed a natural affinity with the nation-states that had guaranteed their religious freedom against the encroachment of the Catholic Church. It is no coincidence that conservative Catholics, such as Duranti's cast of characters, looked to supranational institutions, hoping to weaponise human rights against states they believed were unfavourable to their interests. At the same time, the essays in this volume offer an important corrective to the notion, advanced by Moyn and Duranti, that Christianity necessarily implies conservatism. The chapters by David Lantigua, Vincent Lloyd and James Chappel investigate Christian critiques of human rights from figures on the left who considered liberal or neoliberal rights to be insufficiently attentive to the 'rights of poor and dispossessed peoples.' ${ }^{35}$

Nevertheless, as Shortall and Steinmetz-Jenkins note, a 'robustly Christian rights framework' hardly represents a solution in and of itself to the inadequacies of human rights. ${ }^{36}$ Christian interpretations of rights can be 'emancipatory or exclusionary', ${ }^{37}$ the latter especially in the case of Muslims in contemporary right-wing discourse, but women and LGBTQ people may be similarly affected. Though largely beyond the scope of this volume, the same problems blight other religious interpretations of human rights. The same has been said for 'group rights' - the rights of particular communities within a multicultural society - as Susan Miller Okin famously declared in Is Multiculturalism Bad for Women? ${ }^{38}$ Martha Nussbaum and Seyla Benhabib have likewise argued that only a liberal rights regime, rooted in protections for each individual, can ensure that women and other vulnerable groups enjoy the full benefits of human rights. ${ }^{39}$ In other words, any so-called 'rights' framework which allows for flexible moral or legal norms on the basis of different cultural practices or the privileging of 'communal' over 'individual rights' necessarily harms those who do not hold power within these groups or societies.

Should we, then, insist - as some commentators have - that Christianity and all other religious or cultural practices must be kept strictly separate from debates about rights? Clearly, this is neither

and Christopher P. Vogt, 'Fostering a Catholic Commitment to the Common Good: An Approach Rooted in Virtue Ethics', Theological Studies, 68 (2007), 394-417.

32 Shortall and Steinmetz-Jenkins, Christianity and Human Rights Reconsidered, 11, 27.

33 Ibid., 11.

34 For the former, see the discussion of Emmanuel Mounier's flirtation with the Vichy regime in John Hellman, The Knight-Monks of Vichy France: Uriage, 1940-1945 (Montreal: McGill-Queen's University Press, 1993); on the latter, see Piotr H. Kosicki, Catholics on the Barricades: Poland, France, and 'Revolution', 1891-1956 (New Haven, CT: Yale University Press, 2018).

35 Shortall and Steinmetz-Jenkins, Christianity and Human Rights Reconsidered, 246.

36 Ibid., 9 .

37 Ibid., 8 .

38 Susan Moller Okin, Is Multiculturalism Bad for Women? (Princeton, NJ: Princeton University Press, 1999). See also the edited volume written as a response to Moller Okin's 1999 book: Susan Moller Okin, Joshua Cohen, Matthew Howard and Martha C Nussbaum, eds., Is Multiculturalism Bad for Women? (Princeton: Princeton University Press, 2011).

39 See Martha Nussbaum, 'Religion and Women's Human Rights', in Paul J. Weithman, ed., Religion and Contemporary Liberalism (Notre Dame, IN: University of Notre Dame Press, 1997), 93-121 and Seyla Benhabib, 'Cultural Complexity, Moral Interdependence, and the Global Dialogical Community', in Martha C. Nussbaum, Jonathan Glover and World Institute for Development Economics Research, eds., Women, Culture, and Development: A Study of Human Capabilities, Wider Studies in Development Economics (Oxford: Clarendon Press, 1995), 235-55. 
desirable nor feasible. Instead, this wonderful volume offers ample opportunity to evaluate both the criticisms of human rights offered by Christians and their proposed solutions. In short, by considering how Christians have grappled with, contributed to and sought to mobilise human rights, we gain insight into an ideal which has proved of enduring interest precisely because of how contested and malleable human rights have been and remain today.

Two of the works under review stand in contrast to Duranti's and Shortall and Steinmetz-Jenkins's emphasis on deconstructing the meaning of human rights by looking at the beliefs and ideologies of its various proponents. Johannes Morsink and Steven L.B. Jensen start from the radically different premise that human rights represent an unmitigated good in the world. The aim of their books is to show where these benevolent rights came from and, particularly for Morsink, how they can be used.

Morsink's stated purpose in The Universal Declaration of Human Rights and the Challenge of Religion is to provide an intellectual toolkit to enable the language of human rights to bridge the everincreasing political and religious divides in today's world. ${ }^{40}$ A passionate defender of the UDHR, to which he has devoted three monographs, ${ }^{41}$ Morsink sets out to show that the UDHR was 'crafted with the help of the world's religious traditions and [to] argue that those with religious commitments have no good reasons to withdraw their initial support'. ${ }^{42}$ Central to this argument is the concept of 'benign secularism'. ${ }^{43}$ Morsink considers the secular framing of the UDHR to be 'benign' because it is not anti-religious, but rather provides human rights with a 'nonreligious foundation, meaning that we can enter the domain of international human rights via our own unaided powers of reason and conscience. ${ }^{44}$

The book develops these claims using the framework of Charles Taylor's Modern Moral Order, first discussing the seeming consensus in the world's major faith traditions around the secular framing of the UDHR in the late 1940s, before tackling the arguments of 'religious literalists' in the United States and in various Muslim-majority nations. Using a Rawlsian analysis of the duties of civility and 'public reason', Morsink seeks to resolve perceived tensions between the secular UDHR and religious fundamentalism. ${ }^{45}$ The final section delves more deeply into an investigation of reason and, especially, conscience. Morsink argues that reason is secondary to conscience in providing an 'epistemic path to human rights'. ${ }^{46}$ Evolutionary biology, he suggests, reveals that 'there is room in human nature for genuinely altruistic behaviour that places the wellbeing of another person before our own', and it is this impetus - understood here as conscience - which underpins the language of human rights. ${ }^{47}$ In short, while insisting upon the value of religious people and faith traditions in support of human rights, Morsink firmly rejects natural law or theistic grounding for rights in favour of a resolutely secular framing in line with the language of the UDHR.

Unlike Duranti's book and Moyn's previous work, which primarily seek to historicise human rights, Morsink's monograph looks resolutely to the present, with an eye to warding off a future in which religious fundamentalism threatens to irrevocably undermine human rights. While not a historian by training, Morsink mines the historical record in order to argue that representatives from the major world religions did indeed support the UDHR at the time of its drafting and, in general, accepted or even advocated its secular framing. However, in Morsink's narrative, the meaning

40 Johannes Morsink, The Universal Declaration of Human Rights and the Challenge of Religion (Columbia: University of Missouri Press, 2017), 3.

41 Johannes Morsink, The Universal Declaration of Human Rights: Origins, Drafting, and Intent (Philadelphia: University of Pennsylvania Press, 1999); Morsink, Inherent Human Rights: Philosophical Roots of the Universal Declaration (Philadelphia: University of Pennsylvania Press, 2009); and Morsink, The Universal Declaration of Human Rights and the Holocaust: An Endangered Connection (Washington, DC: Georgetown University Press, 2019).

42 Morsink, The Universal Declaration of Human Rights and the Challenge of Religion, 8.

43 Ibid., 9.

44 Ibid., 50.

45 Ibid., 92, 114.

46 Ibid., 17.

47 Ibid., 214. 
ascribed to human rights by these religious actors is left uninterrogated. This is perhaps due to Morsink's narrow focus on the drafting procedures in his previous work, while overlooking the wider context in which the UDHR was conceived. The writings of Jacques Maritain, a key figure in the lead-up to the drafting of the UDHR, might have been especially helpful in Morsink's discussion of 'benign secularism'. ${ }^{48}$ In his political theory treatise Man and the State, Maritain offers substantial insight into the reasons for religious figures to support human rights in the second half of the 1940s. ${ }^{49}$ While himself a believer in the divine origin of rights, Maritain put forward the concept of natural law - which he believed to be accessible on the basis of purely secular logic - as both a foundation for rights and an ideological bridge between secular and religious traditions. This has some interesting parallels with Morsink's analysis of reason and conscience, likewise theologically inflected concepts which can nevertheless function in the absence of religion. There is similarly no engagement with Moyn's thesis in Christian Human Rights that the Catholic and Protestant origins of human rights concepts matter for our interpretation of what rights actually meant, as well as their limitations today. ${ }^{50}$ Instead, Morsink posits a near-consensus about human rights, based upon shared horror of the Holocaust, within the major faith traditions at the moment of the drafting of the UDHR. ${ }^{51}$ Both authors agree on the fundamentally secular nature of human rights in their contemporary iteration and acknowledge that religious figures had a crucial role in the formulation of rights. Yet where Moyn seeks to problematise this intervention to demonstrate the multiplicity of interpretations of rights, as do Duranti, Shortall and Steinmetz-Jenkins, Morsink insists upon the possibility of a future consensus in both the meaning and origin of rights.

Jensen's book, by contrast, is situated squarely in the historiographical camp of responses to Moyn's claim in The Last Utopia that human rights as we recognise them today emerged seemingly from nowhere in the 1970s. The question of timing - when human rights had their 'breakthrough', to use Jensen and Moyn's terminology - remains a key preoccupation of scholars of human rights. Jensen argues that countries in the Global South acted as underappreciated and precocious champions of universal human rights in the 1960s, which for Jensen is the true 'normative breakthrough' decade. ${ }^{52}$ His most significant accomplishment is to de-centre the Atlantic world of Europe and North America, traditionally the focus of scholarship on human rights, by revealing key diplomatic interventions by states in the Global South during the 1960s. Jensen does not, however, problematise the timing of human rights by also interrogating the competing meanings of rights which coexisted in time and space. As Shortall and Steinmetz-Jenkins persuasively demonstrate, ideas about rights served radically different political, legal and cultural functions, with a corresponding variety of outcomes. As they put it, 'human rights can mean different things to different people, and this is precisely what ensures both their popularity and their political indeterminacy'. ${ }^{53}$

$\overline{48}$ Morsink mentions the notable contributions of Carlos Romulo (Philippines) and Charles Malik (Lebanon), both devout Christians. However, the absence of Maritain from the section on Roman Catholic support for rights is notable and problematic, given his influence not only in popularising human rights beyond the Church but also in shaping Catholic attitudes towards rights. On Maritain, see Chappel, Catholic Modern, and Moyn, Christian Human Rights.

49 Jacques Maritain, Man and the State, Charles R. Walgreen Foundation Lectures (Chicago: University of Chicago Press, 1951).

50 As discussed above, Shortall, Chappel, Chamedes, Duranti and others have published recent work on the relationship between religion, especially Christianity, and human rights. Their work builds upon Moyn's Christian Human Rights, while also contesting some of his key arguments.

51 Moyn and Duranti both reject the notion, which Morsink has defended in all of his books on the UDHR, that the Holocaust was the reason for the drafting of the UDHR. Instead, they argue, few people knew or cared about the Holocaust in the immediate post-war years, and those that did often found it politically inconvenient to publicly recognise the suffering of European Jews. See especially Marco Duranti, 'The Holocaust, the Legacy of 1789 and the Birth of International Human Rights Law: Revisiting the Foundation Myth', Journal of Genocide Research, 14, 2 (2012), 159-86.

52 Steven L.B. Jensen, The Making of International Human Rights: The 1960s, Decolonization, and the Reconstruction of Global Values (Cambridge: Cambridge University Press, 2016), 4.

53 Shortall and Steinmetz-Jenkins, Christianity and Human Rights, 12. 
A broader purpose in writing the book also appears to be to respond to contemporary critics of human rights in the Global South, for whom rights represent a Western, and often problematically secular, imposition. By highlighting the human rights leadership of Liberia and Jamaica, Jensen tries to rescue human rights from accusations of neo-imperialism under the guise of universalism. Rather than rights being imposed by the 'West' on the 'rest', Jensen shows, it was actually the developed world which failed to support attempts by states in the Global South to enforce human rights and make them truly universal. Religion and race represent key themes in the book's exploration of the successes and failures of human rights within the United Nations in the 1960s. Particularly revealing is Jensen's exploration of the reasons for the failure of the Convention on the Elimination of All Forms of Religious Intolerance, first proposed in 1962. Ironically, two religiously-inflected controversies - the 1967 Six-Day War between Israel and its neighbours and the ongoing persecution of Jews in the Soviet Union - spelled the end of the proposed convention. ${ }^{54}$ Jensen speculates that, had the convention not collapsed, 'there might perhaps have been a different trajectory for the relationship not just between religion and international law but also between religion and global society'. ${ }^{55}$

The story Jensen tells alludes only briefly - despite the book's subtitle invoking 'global values' and a key case study on religion - to the role of Christianity. Jensen considers the Second Vatican Council (1962-5) as a reflection of the broader optimism surrounding human rights in the first half of the 1960s. Indeed, he argues, Vatican II and especially the encyclical Pacem in Terris (1963) placed human rights as 'a central element' of the transformation in Catholic theology and the Church's relationship to the world and other faiths. ${ }^{56}$ Global events in the second half of the decade conspired to undermine this 'liberalization of faith and modernization of religion', which had helped spur the proposed convention on religious intolerance. ${ }^{57}$ Yet there is a missed opportunity for reflection on the parallel failures of human rights innovations and the promise of Catholic theological renewal, which Jensen initially links in his discussion. The reforms of Vatican II famously inspired the emergence of liberation theology in Latin America, led by the Peruvian priest Gustavo Gutiérrez. With its emphasis on 'the preferential option for the poor', liberation theology sought to align the Church with 'those who suffer injustice . . impoverishment and exploitation'. ${ }^{58}$ Without explicitly deploying the language of human rights, the liberation theology movement demanded social and economic safeguards of the sort that accompanied the demands of Jensen's human rights protagonists in the Global South. Yet his book, with its exclusive focus on political rights rather than social and economic rights, overlooks the parallel ambitions and failures of these demands. Indeed, just as the developed world backed away from a more egalitarian interpretation of human rights in the 1960s and 1970s, even as human rights gained in international status, so too the Catholic Church censured liberation theology in Latin America and imposed a conservative interpretation of the legacy of Vatican II.

The failure of this wider interpretation of human rights - based upon equality, not sufficiency - is the subject of Moyn's latest book, Not Enough: Human Rights in an Unequal World. There are more than a few parallels between his critiques of human rights and those elucidated in Pope Francis's Fratelli Tutti. Moyn persuasively contends that the age of human rights since the 1970s has accompanied - and perhaps inadvertently facilitated - the rise of market fundamentalism. Both systems

54 Jensen, The Making of International Human Rights, 165.

55 Ibid., 171-2.

56 Ibid., 147. On how Vatican II came to reverse the longtime Catholic teaching that the Jews were responsible for deicide, that is, the murder of Christ, see John Connelly, From Enemy to Brother: The Revolution in Catholic Teaching on the Jews, 1933-1965 (Cambridge, MA: Harvard University Press, 2012). Vatican II also brought a marked improvement in Catholic-Protestant relations. On the origins of Catholic-Protestant rapprochement, see Udi Greenberg, 'Catholics, Protestants, and the Violent Birth of European Religious Pluralism', American Historical Review, 124, 2 (2019), 511-38.

57 Jensen, The Making of International Human Rights, 165.

58 Leonardo Boff, Faith on the Edge: Religion and Marginalized Existence, 1st edn (San Francisco: Harper and Row, 1989), 23, quoted in Paul Farmer, 'Health, Healing, and Social Justice. Insights from Liberation Theology', in Daniel G. Groody and Gustavo A. Gutierrez, The Preferential Option for the Poor Beyond Theology (Notre Dame, IN: University of Notre Dame Press, 2014), 200. 
have embraced the narrative of 'sufficiency', understood as a minimum floor below which the 'wretched of the earth' ought not to fall, while eschewing any attempt to promote equality either on a national or a global level. ${ }^{59}$ This assertion is revealing in two ways. Firstly, it points to a largely underappreciated shift in human rights ideals from the time of the Universal Declaration of Human Rights in 1948, which Moyn asserts was fundamentally concerned with 'distributive justice', to the contemporary abandonment of any 'fairness beyond sufficiency'. ${ }^{60}$ Secondly, it sets the agenda for the book's intellectual project: charting the longer-term competition between the norms of equality and sufficiency, as well as the eventual triumph of the latter. Focusing on the period from the Enlightenment to the present day, Moyn unveils the tensions between sufficiency and equality within a series of European political projects, from the Jacobins and the nineteenth-century market economy, through the post-war welfare state and finally to contemporary neoliberalism.

The problem with mere sufficiency, Moyn suggests, is that it ultimately undermines social cohesion, the results of which are readily apparent in this age of rising populism in Europe and support for Donald Trump in the United States. Without a concerted effort at promoting equality, in other words, voters may 'feel too different from their fellows to institute guarantees even for a basic minimum'. ${ }^{61}$ The book sets out to challenge human rights defenders to examine critically their narrow focus on preventing the very worst abuses and suffering, while neglecting to challenge the broader societal framework that has made inequality more dangerous to civil society than ever before. Moyn deploys the history of political debates about equality and sufficiency to point to a different possible future for human rights in which equality might once again feature prominently, as it did in the immediate post-war years.

In explaining the shift from an 'age of national welfare' to an 'age of neoliberalism', Moyn gives pride of place to the welfare state of the post-Second World War era, especially in Western Europe. It was in this context of comprehensive welfare reform in Europe and, to a more limited degree, in the United States, that the UDHR came about. This, Moyn suggests, makes the UDHR a reflection of the social and economic rights already accomplished in some national contexts, rather than a pioneer of these rights, as scholars like Morsink have argued. Furthermore, with the UDHR containing no enforcement mechanism, the nation-state remained the only site in which rights could be enacted, as Hannah Arendt famously pointed out in chapter nine of The Origins of Totalitarianism. ${ }^{62}$

Christianity features rather indirectly in most of Moyn's narrative. Yet it is striking how, in Moyn's analysis, the welfare state embodies the same compromise between 'capital' and 'labour' that Catholic social teaching and eventually Christian democracy advocated from the 1890s to the mid-twentieth century. ${ }^{63}$ 'Ideologies of class compromise', in other words, facilitated the form of government which did the most to shore up the living standards of ordinary people - especially, of course, white men. Nevertheless, the narrative presented here, in which Christian democratic triumph heralded a new era of relative equality, challenges Moyn's interpretation of Christianity as inherently conservative in his previous book, Christian Human Rights. While a number of scholars have questioned the 'conservative' label ascribed to Christianity in this context, ${ }^{64}$ Moyn acknowledges in this latest work the significant overlap of Christian democracy with the social democracy that took root in the United Kingdom and the Nordic countries. Proponents of the former, he notes, had 'slightly less enthusiasm for the state' than did social democrats, but they nevertheless proposed similarly redistributive welfare states, building on the vision of social justice put forward in Pius XI's Quadragesimo Anno (1931). ${ }^{65}$

\footnotetext{
59 Samuel Moyn, Not Enough: Human Rights in an Unequal World (Cambridge, MA: Harvard University Press, 2019$), 8$.

60 Ibid., 44, 3.

61 Ibid., 5 .

62 Hannah Arendt, The Origins of Totalitarianism, new edn (New York: Harcourt Brace Jovanovich, 1973).

63 Moyn, Not Enough, 32.

64 See the chapters by John Milbank, Julian Bourg, James Chappel, Sarah Shortall, Gene Zubovich and P. MacKenzie Bok in Shortall and Steinmetz-Jenkins, eds., Christianity and Human Rights Reconsidered.

65 Moyn, Not Enough, 50-1.
} 
Taken together, the books under review contend with key debates in the field of human rights and their relationship with Christianity, both in the past and today. Jensen and Morsink essentially embrace the standard, liberal view on human rights. Jensen offers an important corrective to the notion of human rights as a 'Western' product, while Morsink's analysis offers an intellectual and ethical blueprint to reconcile religious conceptions of rights with the secular-liberal rights framework. By contrast, Moyn, Duranti, Shortall and Steinmetz-Jenkins consider the religious and theological influences of human rights interlocutors to be of paramount importance. Their work explores what the history of Christian influence on, and critiques of, ideas about rights can tell us both about human rights themselves and about the reasons for ongoing tensions between Christianity and human rights to this day.

While populist and far-right invocations of the supposed 'Judeo-Christian' origins of rights have garnered much attention, the works under consideration reveal that the relationship between Christianity and human rights has a much longer history of contestation, selective appropriation and mutual influence. Enduring misalignment between Christianity and human rights is therefore not just a matter of fundamentalist Christians in the present-day United States breaking away from a previous liberal consensus on rights, as Morsink suggests. Instead, it is indicative of the tensions inherent to human rights and the way Christians have (mis)used them. In the same way that we should reject the idea of human rights as the exclusive domain of one particular political ideology - whether liberal, progressive or conservative - Christianity itself transcends the left-right binary in interesting and revealing ways. ${ }^{66}$ By considering the political and theological concepts that guide Christian interactions with human rights, we can gain a greater appreciation of the remarkable malleability of both Christianity and human rights. Whether this recognition can be made 'usable' for our present moment is subject to debate, but recognising the multiplicity of meanings of both Christianity and human rights is one step towards understanding how we got to where we are today.

\footnotetext{
66 Sarah Shortall, 'Theology and the Politics of Christian Human Rights', Journal of the History of Ideas, 79, 3 (2018), 445-60.
} 